\title{
PHOSPHATE SOLUBILIZING BACTERIA ISOLATED FROM Pennisetum clandestinum ASSOCIATE TO LIVESTOCK SYSTEMS IN THE ANDEAN AREA
}

\section{BACTERIAS SOLUBILIZADORES DE FOSFATO AISLADAS DE Pennisetum clandestinum ASOCIADAS A SISTEMAS GANADEROS EN EL ÁREA ANDINA}

\author{
Diana Beatriz Sánchez ${ }^{1}$, Ruth Milena Gómez ${ }^{2}$, Ana María García ${ }^{3}$, Ruth Rebeca Bonilla ${ }^{4}$.
}

\begin{abstract}
${ }^{1}$ M.Sc. Ciencias Biológicas. Laboratorio de Microbiología de Suelos-Centro de Biotecnología y Bioindustria. Corporación Colombiana de Investigación Agropecuaria (Corpoica). km 14 Mosquera, Cundinamarca, Colombia. E-mail correspondencia: dbsanchez@corpoica.org.co; ${ }^{2}$ B.Sc. Microbiología Industrial. Laboratorio de Microbiología de Suelos-Centro de Biotecnología y Bioindustria. Corporación Colombiana de Investigación Agropecuaria (Corpoica). rmgomezv@unal.edu.co; ${ }^{3}$ B.Sc. Biología. Laboratorio de Microbiología de Suelos-Centro de Biotecnología y Bioindustria. Corporación Colombiana de Investigación Agropecuaria (Corpoica). ana.garcia13@est.uexternado.edu.co ${ }^{4}$ Ph.D. Ciencias Agrícolas. Laboratorio de Microbiología de Suelos-Centro de Biotecnología y Bioindustria. Corporación Colombiana de Investigación Agropecuaria (Corpoica).rbonilla@corpoica.org.co
\end{abstract}

Rev. U.D.C.A Act. \& Div. Cient. 17(1): 423-431, Julio-Diciembre, 2014

\section{SUMMARY}

The grass Pennisetum clandestinum is the base of the dairy systems in high mountain regions in Colombia. Due to its fertilization requirements it is vital to find sustainable alternatives for its management. In this study, four native strains of the genera Azotobacter, Pseudomonas, Micrococcus and Bacillus, isolated from $P$. clandestinum were used. Characterization of growth promotion ability in vitro such as phosphorus solubilization, production of indole compounds and siderophores synthesis was made for all strains, followed by a test under greenhouse conditions using 50\% tricalcium phosphate plus each bacterium. After two months the bacteria's potential to increment height, radical length, leaf and root weight in $P$. clandestinum was measured. The results indicated that the four strains have the ability for plant growth promotion. The treatment with the strain Azotobacter beijerinckii KA206 + 50\% tricalcium phosphate increased significantly $(p \leq 0.05)$ the assessed agronomical variables. These results surpassed the treatment with a $50 \%$ phosphate fertilization in terms of plant performance regarding roots length and dry weight. The four strains exhibited results that were significantly different $(p \leq 0.05)$. These preliminary results suggest the existence of a feasible alternative that could reduce the phosphate fertilization with sources of low solubilization for the dairy production in sustainable agriculture systems.
Key words: Azotobacter sp., Pseudomonas sp., Micrococcus sp., Bacillus sp., phosphorus solubilization.

\section{RESUMEN}

El pasto Pennisetum clandestinum es la base de los sistemas lecheros de las regiones de alta montaña en Colombia. Debido a sus requerimientos de fertilización es vital encontrar alternativas sustentables para su manejo. En este estudios se utilizaron cuatro cepas nativas de los géneros Azotobacter, Pseudomonas, Micrococcus y Bacillus, aisladas de $P$. clandestinum. Se caracterizaron las capacidades de promoción de crecimiento in vitro, las cuales fueron solubilización de fosfatos, producción de compuestos indólicos y síntesis de sideróforos; seguido de un ensayo bajo condiciones de invernadero utilizando una dosis de $50 \%$ de fosfato tricálcico más cada cepa bacteriana. Después de dos meses se midió el potencial de las bacterias para incrementar la altura de la planta, longitud radical, peso foliar y radicular en $P$. clandestinum. Los resultados indicaron que las cuatro cepas cuentan con capacidades de promoción in vitro. La cepa Azotobacter beijerinckii KA206 + 50\% fosfato tricálcico incrementó significativamente $(p \leq 0.05)$ las variables agronómicas evaluadas. Estos resultados sobrepasaron el tratamiento con $50 \%$ de la dosis de fertilización fosfatada en términos de longitud y peso seco de la raíz. Las cuatro cepas arrojaron resultados significativamente diferentes ( $\mathrm{p} \leq 0.05)$. 
Este resultado preliminar sugiere una alternativa factible que podría reducir la fertilización fosfatada con fuentes de baja solubilización en la producción lechera en sistemas de agricultura sustentable.

Palabras clave: Azotobacter sp., Pseudomonas sp., Micrococcus sp., Bacillus sp., solubilización de fósforo.

\section{INTRODUCTION}

The grass Pennisetum clandestinum originally from tropical latitudes of central Africa is widely distributed in the Andes regions, characterized of low temperatures and high latitudes (Ataroff \& Naranjo, 2009). In Colombia, in high mountain areas (> 2000masl), P. clandestinum has been established as the base of the middle and high intensity dairy systems (Murgueitio, 2000; Carulla et al. 2004; Mila \& Corredor, 2004).

This perennial species has been of interest among researchers due to its high growth rate and good root development, as well as, high nutritional properties as a forage species (Jeffery, 1971). It has been pointed out that the protein content is between the 14 and $25 \%, 30$ and 35 days after cutting. Besides, $P$. clandestinum has been reported as highly resistant to droughts, flooding and salinity conditions (Muscolo et al. 2003; 2013).

P. clandestinum thrives well in fertile soils with high levels of nitrogen. It is very sensitive to the lack of magnesium, iron, potassium and other minerals. Regarding phosphorus, although this grass is very efficient in the use of this element, high available soil concentrations are required for the initial establishment of pasture (Marais, 2001).

Considering the above, under unsuitable soil nutritional conditions and soil degradation process, there is low protein content in the tropical pastures. Due to this lack, the pastures respond positively to chemical fertilization (Marais, 2001; Barton et al. 2009), consisting in $200 \mathrm{~kg} \mathrm{ha}^{-1} \mathrm{year}^{-1}$ and $137 \mathrm{~kg} \mathrm{ha}^{-1}$ year $^{-1}$ of $\mathrm{P}_{2} \mathrm{O}_{5}$ for a yield of 8 tha $^{-1}$ year ${ }^{-1}$. However, due to high economic and ecological costs of this fertilization system it is necessary to develop biotechnological alternatives that allow a good performance and increase in the quality of these pastures.

Environmentally friendly technologies have considered the implement of plant growth promoting rhizobacteria (PGPR), which inhabit the soil and are isolated from the rhizosphere. The effects of these microorganisms in plant development are evident, including beneficial influence on seed germination, seedling emergence and plant growth (Sánchez et al. 2014). The use of these microorganisms has been extensively reported due its positive effect on the development of plant species of the genus Pennisetum (Hameeda et al. 2006; De
Morais et al. 2012). Among the direct effects of PGPR on plants are the production of plant growth promoters, siderophores synthesis and mineral solubilization (Asghar et al. 2002; Hameeda et al. 2006). These effects may increase the nutrient availability for the plant or facilitate its colonization by other beneficial microorganisms (Bashan et al. 2012).

Some PGPR make phosphorus available from insoluble compounds that would normally not be available for plant absorption (Yadav et al. 2014). Thus, primary mechanisms for phosphorus solubilization are proton excretion, organic acids production and phosphatases biosynthesis, the latter when phosphorus sources are organic. Regarding organic acids, these may chelate cations as iron or aluminum which are present in soil and can form complexes with $\mathrm{P}$, releasing $\mathrm{P}$ to be assimilated by plants. In addition, these acids can block absorption sites on soil particles enabling it to be available for plants. This mechanism has been previously associated with effects on growth promotion in diverse vegetable species. In this way, inoculation of plants with microorganisms capable to solubilize phosphorus, might improve health and plant development or even increase crop yield (Behera et al. 2014).

In addition to phosphorus solubilization, indolic compounds and siderophores production by microorganisms has been reported for having positive effects in plant growth promotion. Indolic compounds stimulate root system formation, development and growth (Tsavkelova et al. 2007), and siderophores production is recognized by its effect on increasing iron availability for plants, due to chelation activity in soil. These mechanisms are related to growth and plant development variable increases such as length, height, biomass production and seed germination percentages (Sharma \& Johri, 2003).

The aim of this study was to characterize different bacterial genera as plant growth rhizobacteria promoters of $P$. clandestinum plants for the development of possible biofertilizers, allowing to take properly advantage from Colombian soils biodiversity in the Andean zone and to reduce cost in fertilization.

\section{MATERIALS AND METHODS}

Experiment location and bacteria strains: The experiment was developed at the research center "Tibaitatá - Corporación Colombiana de Investigación Agropecuaria (CORPOICA)", located in Mosquera way km 14 at coordinates 4.71 ${ }^{\circ} \mathrm{N}, 74.23^{\circ} \mathrm{O}$ and $2.291 \mathrm{~m}$ above the sea level.

Four bacteria isolates were assessed in this study: Bacillus sp. K24, Microccus lectus K32, Pseudomonas sp. K35, and Azotobacter beijerinckii KA206. These microorganisms belong to the Soil Microbiology Laboratory Collection from the 
Center for Biotechnology and Bioindustry. The strains were previously isolated from $P$. clandestinum rizosphere in Mosquera, Cundinamarca.

Characterization of plant growth promotion mechanisms in vitro: Indolic compounds production was estimated using the colorimetric test described by Glickmann \& Dessaux (1995). K-lactato medium supplemented with tryptophan was used for this (Carreño-López et al. 2000). Microorganism incubation was carried out for $72 \mathrm{~h}$ at $150 \mathrm{rpm}$ in complete darkness in the culture medium indicated. Sarkowsky reagent was used for indole production determination $\left(12 \mathrm{~g} \mathrm{~L}^{-1} \mathrm{FeCl}_{3}\right.$ in $7.9 \mathrm{M} \mathrm{H}_{2} \mathrm{SO}_{4}$ ) with a 1:1 relation between the reagent and the supernatant from microorganism culture. The reaction lasted for $30 \mathrm{~min}$ in darkness. Indolic compounds concentration was analyzed by spectrophotometry at 540nm.

Quantitive determination of tricalcium phosphate solubilization in liquid medium was accomplished using Pikovskaya broth $\left(\mathrm{g} \mathrm{L}^{-1}\right)$ : Glucose 10; $\left(\mathrm{NH}_{4}\right)_{2} \mathrm{SO}_{4} 0.5 ; \mathrm{MgSO}_{4} 0.1 ; \mathrm{KCl}$ 0.2; yeast extract $0.05 ; \mathrm{Ca}_{3}\left(\mathrm{PO}_{4}\right)$ 2.5. Microorganisms were incubated for 5 days at $30 \pm 2^{\circ} \mathrm{C}$ and 150rpm (Pikovskaya, 1948). The supernatant from each culture and the control treatments were used for phosphorus content measuring (Fiske \& Subbarow, 1925).

For siderophores synthesis determination, it was made a bacterial suspension from each strain in study in $\mathrm{NaCl} 0.85 \%$ at an $\mathrm{OD}_{600}=0.500$. Aliquots of $10 \mu \mathrm{L}$ from the suspension were streaked by triplicate on petri dishes with CAS medium $\left(\mathrm{g} \mathrm{L}^{-1}\right)$ : Chrome azurol S(CAS), 0.06; FeIII solution $(1 \mathrm{mM}$ $\mathrm{FeCl}_{3} .6 \mathrm{H}_{2} \mathrm{O}$ ), $10 \mathrm{~mL} ; 1 \mathrm{mM} \mathrm{HCL}, 10 \mathrm{~mL}$; haxadeciltrimetilammoniumbromide (HDTMA), 0.07; Agar, 37.00; glycerol, $10 \mathrm{~mL}$; piperazine-N-N-bis [2 sulfuric acid ethanol](Pipes), 3.24. $\mathrm{pH}$ 6.8; at a one micro droplet proportion per dish, then, were incubated for $48 \mathrm{~h}$ at $30 \pm 2^{\circ} \mathrm{C}$. Positive outputs were distinguished by blue to yellow color turning surrounding the bacterial growth (Schwyn \& Neilands, 1987).
Test under greenhouse conditions: Phosphorus source: $\mathrm{Ca}_{3}\left(\mathrm{PO}_{4}\right)_{2}$ Tricalcium phosphate (TF), low solubilization in water and not available to the plant.

In this evaluation, a complete randomized design was used, with seven treatments: T0. Control; T1. 100\% TF, T2. 50\% TF, T3. 50\% TF + K24, T4. 50\% TF + K32, T5. 50\% TF + K35 y T6. 50\% TF + KA206, and five repetitions for each treatment. Chemical fertilization was based on soil analysis (12.23\% OM; $2.7 \mathrm{P}\left(\mathrm{mg} \mathrm{kg}^{-1}\right)$; 0.72K; $1.20 \mathrm{Mg}$; $2.32 \mathrm{Ca}(\mathrm{Cmol}$ $\left.\left.\mathrm{kg}^{-1}\right) ; \mathrm{pH}=5.5\right)$, using as phosphorus source tricalcium phosphate. The assessed variables were: plant height $(\mathrm{cm})$, root length $(\mathrm{cm})$, shoots dry weight $(\mathrm{g})$ and root dry weight $(\mathrm{g})$. Each treatment was inoculated with $5 \mathrm{~mL}$ of cellular suspension at $1 \times 10^{8} \mathrm{UFC} \mathrm{ml}^{-1}$ concentration in Luria Bertani medium $\left(\mathrm{g} \mathrm{L}^{-1}\right)$ : Tryptone 10 , yeast extract $5, \mathrm{NaCl} 10$. The experiment was kept under greenhouse conditions for two months.

Statistical analysis: Data were statistically evaluated using an ANOVA and Tukey`s HSD Test with 95\% confidence level.

\section{RESULTS AND DISCUSSION}

Characterization in vitro of plant growth promotion features: Results indicated that all strains have the ability to solubilize the P source evaluated. Bacillus sp. K24 (31.37 $\left.\mathrm{mg} \mathrm{L}^{-1}\right)$ and Azotobacter beijerinckii KA206 (30.17 $\left.\mathrm{mg} \mathrm{L}^{-1}\right)$ strains displayed the best results with statistical significant differences among other treatments ( $p \leq 0.05)$. In relation to indolic compounds production there were a similar behavior within all assessed microorganisms where Microccus lectus K32 (10.72 $\left.\mu \mathrm{g} \mathrm{mL}^{-1}\right)$ and A. beijerinckii KA206 (9.43 $\mu \mathrm{g} \mathrm{mL}^{-1}$ ) strains exhibited higher values. However, regarding to siderophores synthesis M. lectus K32 strain was the only one lacking the activity (Table 1).

Table 1. Characterization of in vitro growth promotion features of the four bacteria strains evaluated.

\begin{tabular}{|l|l|l|l|}
\hline $\begin{array}{l}\text { Bacterial } \\
\text { strain }\end{array}$ & Indolic compounds & $\begin{array}{l}\text { Soluble phosphorus } \\
(\mathrm{ppm})\end{array}$ & $\begin{array}{l}\text { Index of synthesis of } \\
\text { siderophores (mm) }\end{array}$ \\
\hline K24 & $6.69 \pm 0.23^{\mathrm{b}}$ & $31.37 \pm 0.24^{\mathrm{a}}$ & $2.33 \pm 0.07^{\mathrm{b}}$ \\
\hline K32 & $10.72 \pm 1.13^{\mathrm{a}}$ & $18.20 \pm 0.83^{\mathrm{b}}$ & $0.00 \pm 0.00^{\mathrm{c}}$ \\
\hline K35 & $4.52 \pm 0.37^{\mathrm{c}}$ & $29.80 \pm 1.50^{\mathrm{a}}$ & $2.52 \pm 0.08^{\mathrm{a}}$ \\
\hline KA206 & $9.43 \pm 0.51^{\mathrm{a}}$ & $30.17 \pm 1.19^{\mathrm{a}}$ & $2.25 \pm 0.03^{\mathrm{b}}$ \\
\hline
\end{tabular}

Means with no common letters within each variable differ statistically according to Tukey`s test $\mathrm{p} \leq 0.05(\mathrm{n}=3)$ 
Bacillus and Pseudomonas genera have been previously reported as microorganisms that have the three plant growth promotion mechanisms evaluated in vitro in this essay (Ramani, 2011; Gupta et al. 2013). The same results related to the ability for total indole production and siderophores synthesis were reported by Sánchez et al. (2012). Babana et al. (2013) reported for Pseudomonas sp. BR2 strain values of $90 \mathrm{mg} \mathrm{L}^{-1}$ for phosphorus solubilization after seven days of incubation as well as indole production and siderophores synthesis. This latter mechanisms are well known for chelating ferric ion in rhizosphere, which inhibits growth of pathogenic microorganisms which affinity for iron is low. Likewise it allows to increase the element availability to plants when it is found in the form $\mathrm{Fe}^{+3}$, improving plant nutritional balance and therefore plant growth (Glick \& Bashan, 1997).

With regards to the genus Azotobacter other authors have found that it does not have the ability to solubilize high phosphorus concentrations (Husen, 2003), Kumar \& Narula (1999) reported solubilization values between 0.18 and $0.19 \mathrm{mg} \mathrm{L}^{-1}$, results that are below to those ones resulting in this study for the strain A. beijerinckii KA206. Respecting to indole production, it has been found that several species belonging to the genus Azotobacter have the capability to produce different concentrations of these compounds, ranging between 11 y $12.2 \mu \mathrm{g} \mathrm{m} \mathrm{L}^{-1}$ (Fiorelli et al. 1996; Ravikumar et al. 2004), values close to those displayed by KA206. Similarly, siderophores production has been found in previous studies of this genus (Duhme-Klair, 2003).

For the genus Microccus, it has been found as well the capacity to produce indole compounds, solubilize different inorganic phosphorus sources and synthesize siderophores (Dastager et al. 2010). Nevertheless, the last activity was absent in M. lectus K32 strain in this research.

\section{Test under greenhouse conditions}

Height and root length of $P$. clandestinum: Results revealed that inoculation with selected strains positively influenced plants height. Inoculation with A. beijerinckii KA206 (p s 0.05 ) increased plant growth three times in regards to control, whereas that $100 \%$ fertilization treatment did not display differences.

In the same way, root length was increased by bacterial inoculation. Differences were observed with A. beijerinckii KA206 and $M$. lectus K32 compared to the control. However, no differences were evident with $100 \%$ fertilization treatment. In relation to $50 \%$ fertilization dose treatment, it was evident that treatments with the same fertilization dose plus bacterial inoculation displayed higher results. With $A$. beijerinckii KA206 strains, there were statistically significant ( $\leq 0.05)$ differences, revealing increases of $80.6 \%$ (Figure 1).
For plant species of the genus Pennisetum, it has been previously reported that some Pseudomonas sp. bacterial strains are capable of improving height and root length. These features are closely related to plant growth promoting mechanisms in this study, such as phosphorus solubilization and siderophores production (Gupta et al. 2013), which is consistent with results shown by Pseudomonas sp. K35. Siderophores production is linked to iron use by plants, an essential element for photosynthesis and other biological processes. Thus, siderophores allow oxidized iron plant-availability, improving plant nutrition (Taiz \& Zeiger, 2010). Therefore, both Pseudomonas sp. and Bacillus sp. have been distinguished by producing positive significant effects on these variables with up to $30 \%$ increases in plant height and $16 \%$ in root length (Sánchez et al. 2012).

Other studies, have linked Pseudomonas sp. own capability to promote plant growth with efficient rhizosphere colonization leading to a significant increase in plant height and root length, which is mainly related to the strain's competence to solubilize phosphorus (Katiyar \& Goel, 2003). This is due to limitation of available $\mathrm{P}$ to plants that can generate various nutritional deficiencies, so the increase in the element availability due to $\mathrm{P}$ solubilization contributes to plant nutrition and development (Rodríguez \& Fraga, 1999).

Importance of phosphorus in this context lies in its impact on forage quality and hence in the high demand of chemical fertilizers use (Marais, 2001). This is due to phosphorus is an essential macronutrient to plant development, involved in structural stability and energetic efficiency in plants. Therefore, increases in the element availability to plants will be reflected in its development (Taiz \& Zeiger, 2010).

In other grasses such as wheat, it has been pointed out the increases in plant growth caused by strains of the genus Azotobacter, which is also due to phosphates solubilization activity and plant growth promoting substances production such as indole compounds. These mechanisms were observed in A. beijerinckii KA206 strain in this study (Kumar et al. 2001). It has been noted that indole production stimulates cell elongation and apical plant growth, thus this mechanism is closely involved in plant height and root length risings (Taiz \& Zeiger, 2010).

Likewise, the genus Microccus increases up to 100 and $39.2 \%$ root length and plant height respectively, compared to control treatment (Dastager et al. 2010). In this study, increases caused by $M$. lectus K32 strain were statistically significant ( $p \leq 0.05$ ) rising in a $128 \%$ in respect to $50 \%$ fertilization dose treatment (Figure 1).

Shoot and root dry weight of $P$. clandestinum: Results showed that inoculation with microorganisms influenced 


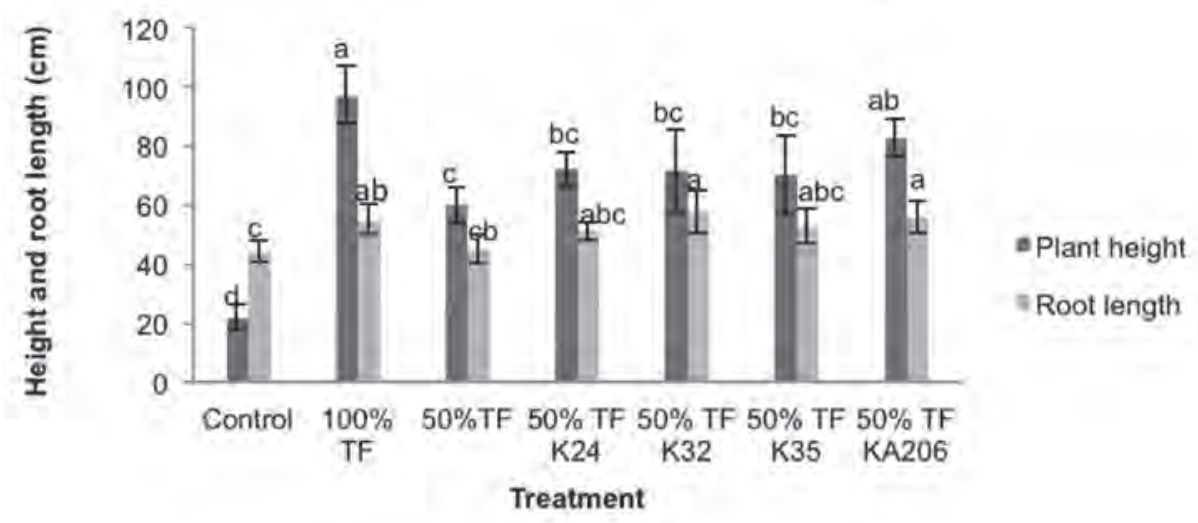

Figure 1. Height $(\mathrm{cm})$ (dark grey bars) and root length (light gray bars) $(\mathrm{cm})$ of $P$. clandestinum. Error bars represent standard deviation. Letters represent significant differences ( $p \leq 0.05)$.

shoot weight positively with tenfold higher values using $A$. beijerinckii KA206 and Bacillus sp. K24 strains compared to the control treatment ( $\mathrm{p} \leq 0.05$ ); whereas no significant differences were found among $100 \%$ fertilization treatment. It was observed that root dry weight from inoculated plants with A. beijerinckii KA206, M. lectus K32 and Bacillus sp. K24 strains, exhibited a significant increase ( $\mathrm{p} \leq 0.05)$, in relation to control, $100 \%$ and $50 \%$ fertilization treatments. Results obtained with A. beijerinckii KA206 strain stand out because of its best performance in root dry weight variable (Figure 2).

In relation to the increase in plant dry weight, it should be pointed out that the rise in values of root biomass has significant effects on plants ability to absorb nutrients from the soil as it represents a greater exploration on soil (Antoun \& Prevost, 2006). In this sense, several studies have demon- strated that auxin type 3-indolacetic acid (IAA) has a notable impact on root development of plants (Lambrecht et al. 2000; Tsavkelova et al. 2006; Ashrafuzzaman et al. 2009). Taking this into account, it is important to emphasize that the four strains had the capacity to produce indolic compounds, which may be related to the improvement of plant development, compared to the control and fertilized treatments (Figure 2).

In the genera Azotobacter, Pseudomonas, Bacillus and Micrococcus, the capacity to increase dry matter production is related to mechanisms such as phosphorus solubilization, indole production and siderophores synthesis, which has been previously reported (Kumar et al. 2001; Dastager et al. 2010). Therefore, inoculation with phosphate solubilizing microorganism improve dry weight on treated plants. Accord-

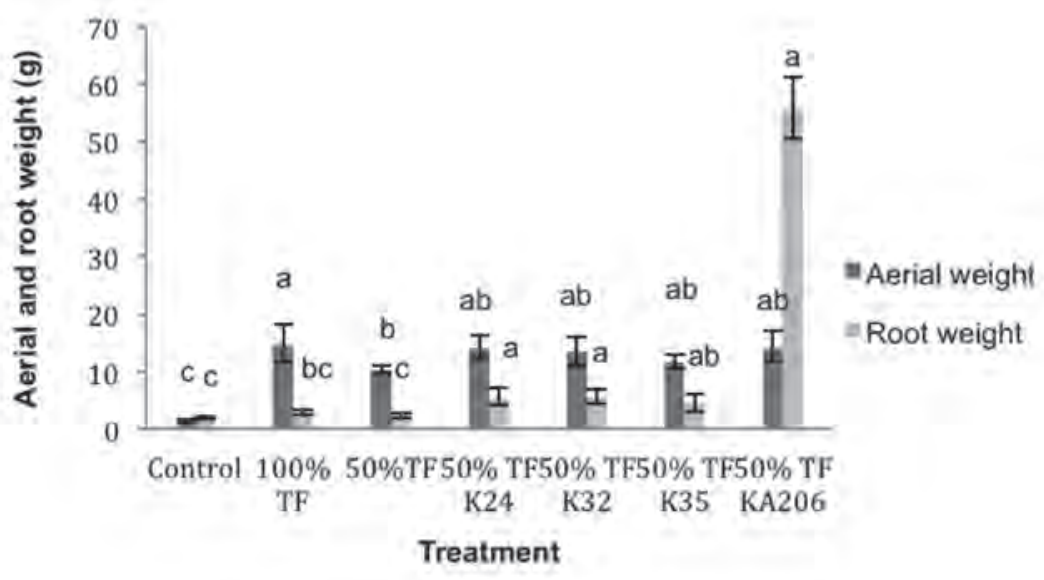

Figure 2. Aerial weight (g) (dark grey bars) and root weight (light grey bars) (g) for $P$. clandestinum. Error bars represent standard deviation. Letters represent significant differences $((p \leq 0.05)$. 
ing to Kumar et al. (2001), this fact may be associated with P increases on substratum, incrementing at the same time its absorption by plants. The latter has been previously reported for the genera Azospirillum and Azotobacter, which are capable of solubilizing phosphorus. Thus increasing capture of phosphorus by plants, when these are inoculated, is related with additions on dry matter production (López-Ortega et al. 2013). So, in accordance with Chabot et al. (1998), phosphates solubilization might be an effective mechanism for plant growth promotion. In that way, Madigan et al. (2004) and Fernández et al. (2005) have noted that since microbial metabolism is capable of releasing trapped phosphorus in insoluble compounds, it is important to take into account the use of microorganisms to increase phosphorus plant uptake.

In addition, it is important to emphasize that this test was carried out on soil which may contain some other sources of phosphate compounds not available for plants; however they could become available due to microorganisms activity. Besides, it should be outlined that the phosphate fertilization dose used in inoculated treatments was 50\%. In this way, the results obtained with these treatments surpassed the treatment with the same fertilization dose and without inoculation and also in some cases the treatment with $100 \%$ fertilization with statistically significant differences ( $p \leq 0.05)$.

Nevertheless, for grasses, it has been previously reported that indole compounds, siderophores production and phosphorus solubilization is related to plant growth promotion, increasing values of variables associated with growth and plant development (Castanheira et al. 2014). Therefore, accomplished results can not only be attributed to phosphorus solubilization but also to the other mechanisms assessed in this assay and also to those not evaluated as biological nitrogen fixation, earlier and widely conferred for the genus Azotobacter (López-Ortega et al. 2013).

Conforming to the response displayed by $P$. clandestinum to inoculation with phosphate solubilizing bacteria, this alternative emerges as a way for using low solubility phosphorus sources plus microbial inoculants instead of using chemical phosphate fertilization. The preceding can make production systems sustainable over time within an organic system.

The presented results contribute to sustainability concept and its application in production systems. On the other hand, more research is needed to elucidate how these bacteria play a role in $P$. clandestinum growth. Thus, the strains used in this research ought to be evaluated in more experiments under greenhouse and field conditions to confirm its potential as plant growth promoters.

In conclusion, the use of this microorganism may lead to a substantial reduction in chemical fertilizers application and therefore in production costs, transforming the livestock system in a sustainable one at different levels such as economic, environmental and social.

Acknowledgment: The authors would like to render thanks to the Colombian Ministry of Agriculture and Rural Development and to the Soils Microbiology Laboratory-Corpoica. Conflict of interest: The manuscript was prepared and revised by all authors, who declare the absence of any conflict that may place the validity of presented results in risk.

\section{BIBLIOGRAPHY}

1. ANTOUN, H.; PREVOST, D. 2006. En: Ecology of plant growth promoting rhizobacteria.PGPR: Biocontrol and Biofertilization. 1a ed. Dordrecht (Netherlands) Springer. p.1-38.

2. ASGHAR, H.N.; ARSHAD, M.; KHALIQ, A. 2002. Relationship between in vitro production of auxins by rhizobacteria and their growth-promoting activities in Brassica juncea L. Biol. Fert. Soils. (Berlin). 35:231237.

3. ASHRAFUZZAMAN, M.; ISLAM, M.; ISMAIL, M.;SHAHIDULLAH, S.; HANAFI, M. 2009. Evaluation of six aromatic rice varieties for yield and yield contributing characters. Int. J. Agri. Biol. (Pakistan). 11:616-620.

4. ATAROFF, M.; NARANJO, M. 2009. Interception of water by pastures of Pennisetum clandestinum Hochst Ex Chiov and Melinis minutiflora Beauv. Agr. Forest. Meteorol. (Netherlands). 149:1616-1620.

5. BABANA, A.H; DICKO, A.; MAÏGA, K.; TRAORÉ, D. 2013. Characterization of rock phosphate-solubilizing microorganisms isolated from wheat (Triticum aestivum L.) rhizosphere in Mali. J. Mıcrobıol. Mıcrobial Res. (United States). 1(1):1-6.

6. BARTON, L.; WAN, G.; BUCK, R.; COLMER, T. 2009. Does $N$ fertilizer regime influence $N$ leaching and quality of different-aged turfgrass (Pennisetum clandestinum) stand. Plant Soil (Netherlands). 316:8196.

7. BASHAN, Y.; SALAZAR, B.G.; MORENO, M., LÓPEZ, B.R.; LINDERMAN, R.G. 2012. Restoration of eroded soil in the Sonoran Desert with native leguminous trees using plant growth-promoting microorganisms and limited amounts of compost and water. J. Environm. Managem. (United States). 102:26-36. 
8. BEHERA, B.C.; SINGDEVASACHAN, S.K.; MISHRA, R.R.; DUTTA, S.K.; THATOI, H.N. 2014. Diversity, mechanism and biotechnology of phosphate solubilising microorganism in mangrive - A review. Biocatal. Agr. Biotechn. (Netherlands). 3:97-110.

9. CARREÑO-LÓPEZ, R.; CAMPOS-REALES, N.; ELMERICH, C.; BACA, B.E. 2000. Physiological evidence for differently regulated tryptophan-dependent pathways for indole-3- acetic acid synthesis in Azospirillum brasilense. Mol. Gen. Genom. (United States) 264(4):521-530.

10. CARULLA, J.; CÁRDENAS, E.; SÁNCHEZ, N.; RIVEROS, C. 2004. Valor nutricional de los forrajes más usados en los sistemas de producción lechera especializada de la zona andina colombiana. (Colombia). En: Seminario Nacional de Lechería Especializada: "Bases Nutricionales y su Impacto en la Productividad" Eventos y Asesorías Agropecuarias EU (ed). Medellín, Septiembre 1 y 2. p.21-38.

11. CASTANHEIRA, A.; DOURADO, A.C.; ALVES, P.I.; CORTÉS-PALLERO, A.M.; DELGADO-RODRÍGUEZ, A.I.; PRAZERES, A.; BORGES, N., SÁNCHEZ, C.; BARRETO, M.T.; FARELEIRA, P. 2014. . Annual ryegrassassociated bacteria with potential for plant growth promotion. Microbiol. Res. (Netherlands). Available at: http://dx.doi.org/10.1016/j.micres (accessed 12/10/2013).

12. CHABOT, R.; BEAUCHAMP, C.; KLOEPPER, J.; ANTOUN, H. 1998.Effect of phosphorus on root colonization and growth promotion of maize by bioluminescent mutants of phosphate-solubilizing Rhizobium leguminosarum Biovar phaseoli. Soil Biol. Biochem. (Netherlands). 30(12):1615-1618.

13. DASTAGER, S.; DEEPA, C.; PANDEY, A. 2010. Isolation and characterization of novel plant growth promoting Micrococcus sp. NII-0909 and its interaction with cowpea. Plant Phisiol. Biochem. (Italy). 48:987-992.

14. DE MORAIS, R.; QUESADA, D.; REIS, V.; URQUIAGA, S.; ALVES, B.; BODDEY, R. 2012. Contribution of biological nitrogen fixation to Elephant grass (Pennisetum purpureum Schum). Plant Soil. 356:23-34.

15. DUHME-KLAIR, A.K. 2003.Catecholamide siderophores of Azotobacter vinelandii: a comparison of their iron and molybdenum binding properties. J. Inorg. Biochem.. (United States). 96(1):68-68.
16. FERNÁNDEZ, L.; ROJAS, F.; VÁSQUEZ, E.; MEDINA, A. 2005. Bacterias solubilizadoras de fosfato inorgánico aisladas de suelos de la región sojera. Ciencia Suelo. (Argentina). 23:215-220.

17. FIORELLI, F.; PASETTI, L.; GALLI, E. 1996. Fertility-Promoting metabolites produced by Azotobacter vinelandii grown on olive-mill wastewaters. Int. Biodet. Biodegr. (United Kingdom). 38(3-4):165-167.

18. FISKE, C.; SUBBAROW, Y. 1925. The colorimetric determination of phosphorus. J. Biol. Chem. (United States). 66:375-400.

19. GLICK, B.R.; BASHAN, Y 1997. Genetic manipulation of plant growth-promoting bacteria to enhance biocontrol of phytophatogens. Biotechn. Adv. (United States). 15:353-378.

20. GLICKMAN, E.; DESSAUX, Y. 1995. A critical examination of the specificity of the salkowsky reagent for indolic compounds produced by phytopathogenic bacteria. Appl. Environm. Microbiol. (United States). 61(2):793-796.

21. GUPTA, G.; PANWAR, J.; JHA, P. 2013. Natural occurrence of Pseudomonas aeruginosa, a dominant cultivable diazotrophicendophytic bacterium colonizing Pennisetum glaucum (L.). Rev. Br. Appl. Soil Ecol. (Netherlands). 64:252-261.

22. HAMEEDA, B.; RUPELA, O.; GOPAL, R.; SATYAVANI, K. 2006. Application of plant growth-promoting bacteria associated with composts and macrofauna for growth promotion of Pearl millet (Pennisetum glaucum L.). Biol. Fert. Soils (Germany). 43:221-227.

23. HUSEN, E. 2003. Screening of soil bacteria for plant growth promotion activities in vitro. Indian J. Agr. Sci. (Indonesia). 4(1):27-31.

24. JEFFERY, H.I. 1971. Nutritive value of Pennisetum clandestinum base dpasture in a sub-tropical environment. Austral. J. Exp. Agr. Animal Husbandry. (Australia). 11:113-177.

25. KATIYAR, V.; GOEL, R. 2003. Solubilization of inorganic phosphate and plant growth promoyion by cold tolerant mutants of Pseudomonas fluorescens. Microbiol. Res. (Germany).158:163-168.

26. KUMAR, V.; BEHL, R.; NARULA, N. 2001. Establishment of phosphate-solubilizing strains of Azotobacter 
chroococcum in the rhizosphere and their effect on wheat cultivars under greenhouse conditions. Res. Microbiol. (United States).156:87-93.

27. KUMAR, V.; NARULA, N. 1999. Solubilization of inorganic phosphates and growth emergence of wheat as affected by Azotobacter chroococcum mutants. Biol. Fert. Soils. 28:301-305.

28. LAMBRECHT, M.; OKON, Y.; BROEK, A.; VANDERLEYDEN, J. 2000. Indole-3-acetic acid: a reciprocal molecule in bacteria-plant interactions. Trends in Microbiol. (United Kingdom). 8(7):298-300.

29. LÓPEZ-ORTEGA, M.P.; CRIOLLO-CAMPOS, P.J.; GÓMEZ-VARGAS, R.M.; CAMELO-RUSINQUE, M.; ESTRADA-BONILLA, G.; GARRIDO-RUBIANO, M.F.; BONILLA-BUITRAGO, R. 2013. Characterization of diazotrophic phosphate solubilizing bacteria as growth promoters of maize plants. Rev. Col. Biotecn. 15(2):115-123.

30. MADIGAN, M.T.; MARTINKO, J.; PARKER, J. 2004. Brock, Biología de los microogranismos. $10^{\circ}$ ed. Editorial Person Prentice hall. Madrid: 1011p.

31. MARAIS, J. 2001. Factors affecting the nutritive value of kikuyu grass (Pennisetum clandestinum) - a review. Tropical Grasslands (Austria). 35:65-84.

32. MILA, A.; CORREDOR, G. 2004. Evolución de la composición botánica de una pradera de kikuyo (Pennisetum clandestinum) recuperada mediante escarificación mecánica y fertilización con compost. Rev. Corpoica. (Colombia). 5(1):70-75.

33. MURGUEITIO, E. 2000. Sistemas agroforestales para la producción ganadera en Colombia. Pastos Forrajes (Cuba). 3(1):1-11.

34. MUSCOLO, A.; PANUCCIO, M.; ESHELC, A. 2013. Ecophysiology of Pennisetum clandestinum: a valuable salt tolerant grass. Environm. Exp. Bot.. (Netherlands). 92:55-63

35. MUSCOLO, A.; PANUCCIO, M.; SIDARI, M. 2003. Effects of salinity on growth, carbohydrate metabolism and nutritive properties of kikuyu grass (Pennisetum clandestinum Hochst). Plant. Science. (United Kingdom). 164:1103-1110.

36. PIKOVSKAYA, R.I. 1948. Mobilization of phosphorus in soil in connection with vital activity of some microbi- al species. Mikrobiol. (Russian Federation). 17:362370.

37. RAMANI, V. 2011. Effect of pesticides on phosphate solubilization by Bacillus sphaericus and Pseudomonas cepacia. Pesticide Biochem. Physiol. (United States). 99:232-236.

38. RAVIKUMAR, S.; KATHIRESAN, K.; IGNATIAMMAL, S.; BABUSELVAM, M.; SHANTHY, S. 2004.Nitrogenfixing azotobacters from mangrove habitat and their utility as marine biofertilizers. J. Exp. Marine Biol. Eco. (Netherlands). 312(1):5-17.

39. RODRÍGUEZ, H.; FRAGA, R. 1999. Phosphate solubilizing bacteria and their role in plant growth promotion. Biotechn. Adv. 17:319-339.

40. SÁNCHEZ, D.; ROMERO P.; BONILLA, B. 2014. Respuesta de Physalis peruviana L. a la inoculación con bacterias solubilizadoras de fosfato. Rev. Mex. Cienc. .Agr. 5(5):901-906.

41. SÁNCHEZ, D.; GÓMEZ, R.; GARRIDO, M.; BONILLA, R. 2012. Inoculación con bacterias promotoras decrecimiento vegetal en tomate bajo condiciones de invernadero. Rev. Mex. Cienc. Agr. 3(7):1401-1415.

42. SCHWYN, B.; NEILANDS, J. 1987. Universal chemical assays for the detection and determination of siderophores. Analyt. Biochem. (United States). 160:4756.

43. SHARMA, A.; JOHRI, B.N. 2003. Growth promoting influence of siderophore-producing Pseudomonas strains GRP3A and PRS 9 in maize (Zea mays L.) under iron limiting conditions. Microbiol. Res. 158:243248.

44. TAIZ, L.; ZEIGER, E. 2010. Plant Physiology. $5^{\text {th }}$ ed. Ed. SinauerAssociates, Incorporated. (Sunderland. MA). p782

45. TSAVKELOVA, E.; CHERDYNTSEVA, T.; BOTINA, S.; NETRUSOV, A. 2007. Bacteria associated with orchid roots and microbial production of auxin. Microbiol. Res. 162:69-76.

46. TSAVKELOVA, E.; KLIMOVA, S.; CHERDYNTSEVA, T.; NETRUSOV, A. 2006. Microbial producers of plant growth stimulators and their practical use: a review. Appl. Biochem. Microbiol. 42:117-126. 
47. YADAV, J.; VERMA, J.P.; JAISWAL, D.K.; KUMAR, A. Received: 22 January 2014 2014. Evaluation of PGPR and different concentra- Accepted: 15 September 2014 tion of phosphorus level on plant growth, yield and nutrient content of rice (Oryza sativa). Ecol. Eng. (Netherlands). 62:123-128.

\section{Como Citar:}

Sánchez, D.B.; Gómez, R.M.; García, A.M., Bonilla, R.R. 2014. Phosphate solubilizing bacteria isolated from Pennisetum clandestinum associate to livestock systems in the Andean area. Rev. U.D.C.A Act. \& Div. Cient. 17(2): 423-431. 